(C) Springer Science+Business Media, Inc. 2006

10.1007/s00248-006-9035-y

\title{
Tetracyclines and Tetracycline Resistance in Agricultural Soils: Microcosm and Field Studies
}

\author{
Heike Schmitt ${ }^{*}$, Krispin Stoob ${ }^{2}$, Gerd Hamscher ${ }^{3}$, Eric Smit ${ }^{4}$ and \\ Willem Seinen ${ }^{1}$
}

(1) Institute for Risk Assessment Sciences (IRAS), Utrecht University, PO Box 80176, 3508 TD Utrecht, The Netherlands

(2) EAWAG, Dübendorf, Switzerland

(3) Department of Food Toxicology, University of Veterinary Medicine Hannover, Foundation, Hannover, Germany

(4) RIVM, Bilthoven, The Netherlands

\section{* Heike Schmitt \\ Email: heike.schmitt@rivm.nl}

\begin{abstract}
The influence of the use of antibiotics on the prevalence of resistance genes in the environment is still poorly understood. We studied the diversity of tetracycline and sulfonamide resistance genes as influenced by fertilization with pig manure in soil microcosms and at two field locations. Manure contained a high diversity of resistance genes, regardless of whether it stemmed from a farm operation with low or regular use of antibiotics. In the microcosm soils, the influence of fertilization with manure was clearly shown by an increase in the number of resistance genes in the soil after manuring. Spiking of the tetracycline compounds to the microcosms had only little additional impact on the diversity of resistance genes. Overall, the tetracycline resistance genes $\operatorname{tet}(\mathrm{T})$, tet $(\mathrm{W})$, and $\operatorname{tet}(\mathrm{Z})$ were ubiquitous in soil and pig slurries, whereas tet( $\mathrm{Y}), \operatorname{tet}(\mathrm{S}), \operatorname{tet}(\mathrm{C})$, tet $(\mathrm{Q})$, and $\operatorname{tet}(\mathrm{H})$ were introduced to the microcosm soil by manuring. The diversity of tetracycline and sulfonamide [sul(1), sul(2), and sul(3)] resistance genes on a Swiss pasture was very high even before slurry amendment, although manure from intensive farming had not been applied in the previous years. The additional effect of manuring was small, with the tetracycline and sulfonamide resistance diversity staying at high levels for the complete growth season. At an agricultural field site in Germany, the diversity of tetracycline and sulfonamide resistance genes was considerably lower, possibly reflecting regional differences in gene diversity. This study shows that there is a considerable pool of resistance genes in soils. Although it is not possible to conclude whether this diversity is caused by the global spread of resistance genes after 50 years of tetracycline use or is due to the natural background in soil resistance genes, it highlights a role that environmental reservoirs might play in resistance gene capture.
\end{abstract}

\section{Introduction}

Antibiotic resistance of pathogenic bacteria has been recognized as a global public health concern [56]. Recently, the nonhuman application of antibiotics has also been discussed in connection with pathogen resistance $[4,18]$. However, it is widely acknowledged that major data gaps complicate an analysis of the problem of antibiotic resistance. One of them is the role of environmental bacteria as resistance reservoir, linked to the role of antibiotics in the environment as selective pressure for the development of resistance $[3,4]$. 
A major route of the dissemination of antibiotics to the environment is the application of slurry of treated farm animals on agricultural soils $[24,46]$. The total veterinary use of antibiotics is comparable to human use, according to the latest available usage figures from Europe (3465 tonnes veterinary therapeutic use vs 5460 tonnes human use in $1997[19,54])$. Antibiotics entering the soils as contaminants in the manure $[15,26]$ may select for resistant soil bacteria. Subinhibitory concentrations of antibiotics are generally thought to select for resistant populations [9], and the relatively small concentrations of antibiotics detected in soils $[15,25,26,35,47]$ might therefore contribute to an increase in resistance. The manure might also contain fecal bacteria carrying resistance genes, possibly on mobile genetic elements. These might subsequently be horizontally transferred to soil bacteria $[30,48]$, a process that is facilitated by high nutrient availability such as provided by manure [21].

The importance of animal manure for the occurrence of resistance genes in the environment has been shown for soils or groundwater below a pig farm [5, 11, 30]. A transient increase of resistance after manuring has also been observed in the culturable part of the bacterial community [48]. However, little is known regarding the role of antibiotics as an additional selective pressure for the maintenance of antibiotic resistance in the soil environment due to veterinary antibiotic use $[17,28,55]$. For example, previous investigations on aminoglycoside antibiotics were not completely conclusive as to the role of selection pressures in the environment. A high diversity of gentamycin resistance genes in pig manure has been noted [28], and streptomycin-modifying genes were abundant in many habitats with and without selective pressure [55]. Thus, more information is needed from habitats with a clearly characterized selective pressure.

Microcosms enable one to study the effects of selective pressures under controlled circumstances. In previous studies, it has been shown that the exposure of soil microcosms to oxytetracycline leads to adaptation of the bacterial community to the antibiotic, as judged from an increase in the community tolerance and from 16S rDNA denaturing gradient gel electrophoresis (Schmitt, submitted for publication). Here, we build upon these experiments by studying the role of resistance gene diversity in these community changes. Tetracycline and sulfonamide resistance genes have been chosen because these represent the most important veterinary compound classes per volume.

We investigated the effects of both manure and tetracycline amendment on tetracycline resistance in soil by performing microcosm studies with manure and a wide range of antibiotic concentrations. Furthermore, tetracycline and sulfonamide resistance was studied in field situations with agricultural soils undergoing fertilization with manure. The goal of the field studies was to evaluate the input of resistance genes with manure and to study the persistence of these genes in the soil.

\section{Methods}

\section{Setup of Soil Microcosms}

Microcosms were set up by amending agricultural soil samples with pig manure and a range of tetracycline or oxytetracycline concentrations. Soils were sampled from an experimental agricultural site located in Bennekom, the Netherlands [20]. The soil is loamy sand with a $\mathrm{pH}$ of 5.5-6.5. In previous investigations, the soil texture was determined as 3\% clay, $10 \%$ silt, and $87 \%$ sand, and the cation- 
exchange capacity was $5.6 \mathrm{cmol}_{\mathrm{c}} \mathrm{kg}^{-1}$ [36]. The site had received organic fertilizers twice in the last 20 years (NPK fertilizer containing heat-treated cow and chicken manure). Pig manure was sampled from the university stables of the Utrecht University. Manure and urine were collected from a healthy sow that underwent no antibiotic treatment during the last 1.5 months and a slurry was prepared by mixing manure and urine in a mixer. Soil microcosms consisted of $300 \mathrm{~g}$ dry weight subsamples to which the pig manure was added. The slurry quantities approximated the maximum nitrogen soil input $\left(170 \mathrm{~kg} \mathrm{~N} \mathrm{ha}^{-1}\right)$ for nitrate vulnerable zones in the European Union (nitrogen input: 101 and $91 \mathrm{mg} \mathrm{N}$ $\mathrm{kg}^{-1}$ dry weight, equivalent to 157 and $186 \mathrm{~kg} \mathrm{~N} \mathrm{ha}^{-1}$ at a mixing depth of $20 \mathrm{~cm}$; slurry dry matter input: 2.9 and $1 \mathrm{~g} \mathrm{~kg}^{-1}$ dry weight, for the first and second microcosm series, respectively). In the first microcosm experiment, soils were spiked with oxytetracycline (oxytetracycline dihydrate, purity $>99 \%$, SigmaAldrich, St. Louis, MO, USA), resulting in soil concentrations of 0 (in duplicate), $0.5,5,15,50,150,500$, and $1500 \mathrm{mg} \mathrm{kg}^{-1}$ dry weight. Maximum concentrations observed in manured soils are in the range of several hundred micrograms per kilogram [25]. In the second microcosm experiment, soil samples were amended with oxytetracycline $\left(0.1,1,10\right.$, and $100 \mathrm{mg} \mathrm{kg}^{-1}$ dry weight) or tetracycline [tetracycline hydrochloride, purity $>97 \%$ (Fluka, Buchs, Switzerland), at tetracycline concentrations of $0.1,1,10,100$, and $1000 \mathrm{mg} \mathrm{kg}^{-1} \mathrm{dry}$ weight]. Spiking was performed by mixing the above-mentioned manure with the solid compound (or aqueous solutions for the lower amendments) in a kitchen mixer, and then adding the soil subsample to the manure/substance mixture, again mixing with a kitchen mixer for 2 min. Two soil samples amended only with manure and one soil sample amended with water in place of manure served as controls for the second microcosm series. The microcosms were kept in climate chambers at $25^{\circ} \mathrm{C}$, and deionized water was added every few days to maintain the same soil humidity (119 and $150 \mathrm{~g} \mathrm{~kg}^{-1}$ dry weight). Soil samples were taken at day 0 directly after setup of the microcosms, on days 6 and 14 in the first experiment and on day 8 in the second experiment. Microcosms were not kept for longer than 2 weeks, as the temperature and humidity conditions were not deemed representative of field samples for longer time periods.

\section{Field Experiments}

One field experiment was set up in Switzerland. Liquid manure was sampled from a farm where pigs are routinely treated with chlortetracycline, sulfamethazine, and tylosin. The manure was applied on two adjacent parcels of grassland that had been fertilized regularly. However, no manure from intensive pig farming was applied in the last decade to the best of our knowledge. The soil was classified as

loamy Eutric Cambisol (FAO) with a ${ }^{\mathrm{ph}_{\mathrm{CaCl}_{\mathbf{z}}}}$ of 5.5 to 6 and a total organic carbon content of $3.6 \%$ by weight (analyzed in $105^{\circ} \mathrm{C}$ dried samples with a CN Analyser from ThermoQuest, Waltham, MA, USA).

The manure application took place in the end of March and beginning of May 2003. The manure was applied by using a band spreader. The application rate was $30 \mathrm{~m}^{3}$ per hectare (equivalent to $93 \mathrm{~kg} \mathrm{~N} / \mathrm{ha}$ ) following Swiss agricultural practice. A few hours before application, the manure was spiked with additional sulfonamide compounds in order to distinguish between the two parcels and the two applications (sulfathiazol and sulfadimethoxin for the first application, and sulfadiazin and sulfamethoxazol for the second application). Samples taken from the manure spreader were homogenized with a kitchen blender and stored in the dark at $-20^{\circ} \mathrm{C}$ until DNA extraction. 
Soil samples (top $5 \mathrm{~cm}$ ) were taken before and after manure application using a conventional $5-\mathrm{cm}$-diameter split tube core sampler. Twenty-five cores were taken according to the band-spreading pattern from the manure application on each field and mixed with one composite sample in order to have a sample representing the average concentration of the parcel. Samples taken 2 weeks and 6 months before the first manuring event served as controls. Samples taken after $1,4,11,24,45,46,49,56,73$, and 86 days were used to investigate the pattern of the resistance genes in the time course and the concentration of sulfonamide antibiotics.

Field soils were also obtained from an experiment in Germany in which the leaching behavior of veterinary compounds after the application of spiked pig manure was tested on two different soils. One soil was sand $(83.5 \%$ sand, $4.9 \%$ clay, $1.0 \%$ organic carbon, ${ }^{\mathrm{ph}_{\mathrm{CaCl}_{5}}}$ 5.7) that had regularly been fertilized with cattle manure in the last 2 years. This soil did not contain any tetracyclines above the detection limit of $2 \mu \mathrm{g} \mathrm{kg}^{-1}$ [26] before the experiment. The other soil was a silty loam (4.3\% sand, $41.3 \%$ clay, $2.6 \%$ organic carbon, ${ }^{\mathrm{P}_{\mathrm{CaCl}}}{ }_{7.4)}$ that had been regularly fertilized with pig manure in the last 2 years and contained 41 and $27 \mu \mathrm{g}$ tetracycline $\mathrm{kg}^{-1}$ dry soil in the layers $0-10$ and $10-20 \mathrm{~cm}$, respectively. Mixed soil samples were taken in spring (in April), shortly before manure had been applied, from the layers $0-10$ and $10-20 \mathrm{~cm}$. A 9- $\mathrm{m}^{2}$ area of both the sandy soil and the silty loam soil was supplied with $1 \mathrm{~L} \mathrm{~m}^{-2}$ of pig manure $\left(10 \mathrm{~m}^{3} \mathrm{ha}^{-1}\right.$, $2 \%$ dry matter content) that had been spiked with tetracycline and chlortetracycline. Before spiking, the concentrations of tetracycline and chlortetracycline were below the detection limit. Resistance genes were determined in a sample of manure before spiking. The concentrations of tetracycline and chlortetracycline in manure after spiking were 9.5 and $6.4 \mathrm{mg}$ $\mathrm{kg}^{-1}$ pig manure for the sandy soil, and 10.0 and $8.9 \mathrm{mg} \mathrm{kg}^{-1}$ for the silty clay. Both soils were sampled within $2 \mathrm{~h}$ after slurry application. Soils were stored at $-30^{\circ} \mathrm{C}$ until DNA extraction.

\section{DNA Extraction and Polymerase Chain Reaction}

DNA was extracted from $0.5 \mathrm{~g}$ of soil by using a commercial kit (FastSpin kit for soil, Qbiogene, Irvine, CA, USA) according to the specifications of the manufacturer with slight modifications (centrifugation for 2 min after beadbeating, and elution in $70 \mu \mathrm{L}$ water). Genomic DNA from manure samples was extracted using a commercial kit (QIamp $B$ DNA Stool Mini Kit, Qiagen, Valencia, CA, USA), following the instructions of the manufacturer. Raw DNA was purified by use of a resin column (Wizard DNA clean-up system, Promega, Leiden, the Netherlands) following the protocol of the manufacturer; apart from that, $70 \mu \mathrm{L}$ water was used for DNA elution.

The concentration of DNA in the extracts was determined for selected samples by comparing the fluorescence of PicoGreen $\otimes$-amended DNA with the fluorescence of a standard curve generated from phage $\lambda$ DNA (PicoGreen ${ }^{\circ}$ dsDNA kit, Molecular Probes, Breda, the Netherlands) and ranged from 0.9 to $33 \mu \mathrm{g} / \mathrm{g}$ soil (dry weight), with an average of $13 \mu \mathrm{g} / \mathrm{g}$ soil.

Amplification of tetracycline resistance determinants by polymerase chain reaction (PCR) was based on a primer set described previously by Aminov et al. $[5,6]$. The determinants tested in this study included $\operatorname{tet}(A), \operatorname{tet}(B), \operatorname{tet}(C)$, $\operatorname{tet}(E)$, $\operatorname{tet}(\mathrm{H}), \operatorname{tet}(\mathrm{M}), \operatorname{tet}(\mathrm{O}), \operatorname{tet}(\mathrm{Q}), \operatorname{tet}(\mathrm{S}), \operatorname{tet}(\mathrm{T}), \operatorname{tet}(\mathrm{W}), \operatorname{tet}(\mathrm{Y})$, and $\operatorname{tet}(\mathrm{Z})$. Sulfonamide primers were taken from [22] [sul(I)], [13] [sul(II)], and [42] 
[sul(III)]. PCR was typically performed in a volume of $25 \mu \mathrm{L}$, with $10-40 \mu \mathrm{M}$ of each primer, $200 \mu \mathrm{M}$ for each deoxynucleoside triphosphate, $1.25 \mathrm{U}$ of Expand Long Template enzyme mix containing Taq and Tgo DNA polymerase (Roche Applied Sciences, Almere, the Netherlands) and its accompanying reaction buffer 2. Genomic DNA ( $1 \mu \mathrm{L}$, undiluted) served as template. As positive control, DNA extracts of control strains harboring tetracycline resistance genes described in [5, $6]$ were used. Deionized water served as negative control. Reactions were performed in a Hybaid PCR Express or Hybaid Px2 Thermal Cycler (Franklin, MA, USA), with PCR amplification consisting of initial denaturation at $94^{\circ} \mathrm{C}$ for $5 \mathrm{~min}$, followed by 40 cycles of $94^{\circ} \mathrm{C}$ for $20 \mathrm{~s}, 30 \mathrm{~s}$ of annealing at the annealing temperatures shown in Table $1,50 \mathrm{~s}$ of extension at $72^{\circ} \mathrm{C}$, and a final extension step at $72^{\circ} \mathrm{C}$ for $7 \mathrm{~min}$. Aliquots $(5 \mu \mathrm{L})$ were analyzed by gel electrophoresis on agarose gels (2.5\%, Cambrex, Verviers, Belgium) after staining with SybrGold (Molecular Probes). To prevent false-negative results due to PCR-inhibiting substances such as humic acids, a second DNA extraction was performed for the Swiss field soil samples that were negative in the first PCR round, and PCR reactions were additionally undertaken for the new soil DNA extracts and for a 10 -fold dilution of the original extracts.

Table 1 Tetracycline resistance in soil microcosms spiked with pig manure and oxytetracycline (first microcosm study)-influence of soil exposure duration

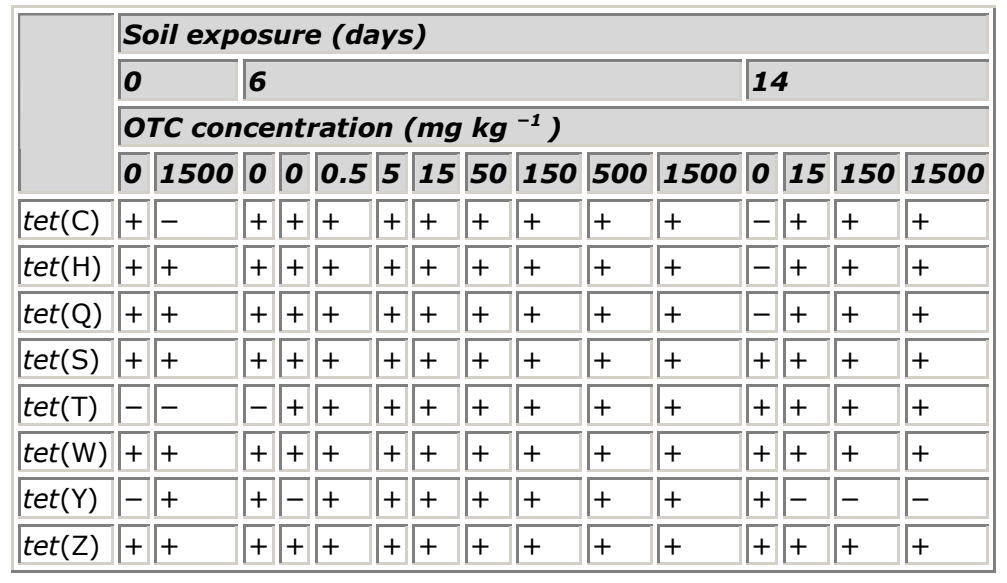

Results of positive findings of tetracycline resistance determinants per soil sample and oxytetracycline concentration after 0,6 , and 14 days of soil exposure. tet(B), tet(E), tet(M), and tet(O) had not been found in selected samples with high spiking concentrations.

For the microcosm samples, a first round of PCR reactions was performed for selected samples (one control and three samples with high concentrations of antibiotic spiked to the soil), and only the tetracycline resistance determinants that gave positive results in at least one sample in the first round were analyzed in all microcosm samples.

\section{Analysis of Soil Samples}

The sample pretreatment performed for the analysis of tetracyclines was recently reported in detail [26]. Briefly, the procedure was as follows: Prior to the extraction of wet soil, the dry weight was determined with a subsample ( $20 \mathrm{~g}$ of each soil sample was incubated at $100^{\circ} \mathrm{C}$ for approximately $24 \mathrm{~h}$ until constant weight was reached). Wet soil or slurry $(1 \mathrm{~g})$ was intensively vortexed with $1.2 \mathrm{~mL} 1 \mathrm{M}$ citrate buffer ( $\mathrm{pH} 4.7)$ in a $10-\mathrm{mL}$ glass tube for $1 \mathrm{~min}$. Ethyl acetate 
$(6 \mathrm{~mL})$ was added, again intensively vortexed for $1 \mathrm{~min}$, and then kept for another $15 \mathrm{~min}$ in an automatic shaker (KS 125 basic, IKA Labortechnik, Staufen, Germany). After evaporation of the organic phase to dryness, the antibiotics were reconstituted in $200 \mu \mathrm{L}$ (soil samples) or $1000 \mu \mathrm{L}$ (liquid manure samples) $90 \%$ acetonitrile and $10 \% 100 \mathrm{mM}$ ammonium acetate in water and subjected to liquid chromatography-tandem mass spectrometry (LC-MS-MS) analysis.

For sulfonamide analysis, soil samples were stored in the dark at $-20^{\circ} \mathrm{C}$, milled (under frozen conditions, with dry ice), homogenized, and divided into aliquots with a sample splitter (Rentsch, GmbH \& Co, Haan, Germany) before analysis. The determination of the sulfonamide concentration of the soil samples was done by pressurized liquid extraction (ASE 200, Dionex, Sunnyvale, CA, USA) followed by LC-MS-MS (TSQ Discovery, Thermo Finnigan, San Jose, CA, USA) (Stoob et al., in preparation).

\section{Results}

\section{First Microcosm Experiment: Effect of Spiking with Oxytetracycline over Time}

The first microcosm experiment revealed that the amount of detected genes was nearly constant over the whole oxytetracycline dose range. The gene diversity was thus not strongly influenced by an additional spiking of the slurry-amended soils with oxytetracycline (Table 1) Analysis of the resistance pattern over time showed that some genes that gave strong signals after 6 days' exposure to manure and oxytetracycline were less clearly detectable directly after soil spiking and in the control soil without oxytetracycline amendment at day 14 . Resistance determinant tet(C) was not consistently found on both days, tet $(\mathrm{T})$ was not detected at day 0 , and $\operatorname{tet}(\mathrm{H})$ and tet( $(\mathrm{Q})$ were not found at day 14 . Furthermore, tet $(\mathrm{Y})$ seemed to disappear after 14 days of soil exposure in all oxytetracycline treatments (although it gave a weak signal in the control soil). At day 0, directly after application of oxytetracycline and manure, the resistance gene abundance was slightly lower than at day 6.

\section{Second Microcosm Experiment: Effect of Manure Versus Spiking with Antibiotics}

When testing soil and manure separately, relatively few genes were found in soil samples before tetracycline and manure treatment, but the pig manure contained all 12 tetracycline resistance genes that it was tested for (Table 2). This difference persisted after the microcosms were set up. Three tetracycline resistance genes were detected both in the water-treated control soil after 7 days and in the soil before treatment. In the water-treated soil, though, there was a weak signal for tet $(\mathrm{Y})$, but tet( $\mathrm{Z})$ could not be detected. In the manure-treated soils, about six to eight tet resistance genes were found, all of which had also been detected in the manure. Among the genes that failed detection, tet(S) was the most frequent. There was no apparent relationship between the antibiotic spiking concentration and the resistance pattern. 
Table 2 Tetracycline resistance in soil microcosms spiked with pig manure and oxytetracycline or tetracycline (second microcosm study)

\begin{tabular}{|c|c|c|c|c|c|c|c|c|c|c|c|c|c|c|c|c|}
\hline \multirow[b]{3}{*}{ (C) } & \multirow{2}{*}{\multicolumn{2}{|c|}{ Pure soil }} & \multirow{2}{*}{\multicolumn{2}{|c|}{ Pure slurry }} & \multicolumn{3}{|c|}{ Control soil } & \multicolumn{4}{|c|}{ Oxytetracycline soil } & \multicolumn{5}{|c|}{ Tetracycline soil } \\
\hline & & & & & \multirow{2}{*}{\begin{tabular}{|l|} 
Water \\
-
\end{tabular}} & \multicolumn{2}{|c|}{ Slurry } & \multirow{2}{*}{$\begin{array}{l}0.1 \\
+\end{array}$} & \multirow{2}{*}{1} & \multirow{2}{*}{\begin{tabular}{|l}
10 \\
+
\end{tabular}} & \multirow{2}{*}{\begin{tabular}{|l|}
100 \\
+ \\
\end{tabular}} & \multirow{2}{*}{$\begin{array}{l}0.1 \\
+ \\
\end{array}$} & \multirow{2}{*}{1} & \multirow{2}{*}{$\begin{array}{l}10 \\
+ \\
\end{array}$} & \multirow{2}{*}{$\begin{array}{l}100 \\
+\end{array}$} & \multirow{2}{*}{$\begin{array}{l}1000 \\
+\end{array}$} \\
\hline & - & - & + & + & & + & + & & & & & & & & & \\
\hline $\operatorname{tet}(\mathrm{H})$ & - & - & + & + & - & + & + & + & + & + & + & + & + & + & + & + \\
\hline $\operatorname{tet}(\mathrm{Q})$ & - & - & + & + & - & + & + & + & - & + & + & + & + & + & + & + \\
\hline $\operatorname{tet}(\mathrm{S})$ & - & - & + & + & - & + & - & + & - & - & - & + & + & + & + & + \\
\hline $\operatorname{tet}(\mathrm{T})$ & + & + & + & + & + & + & + & + & + & + & + & + & + & + & + & + \\
\hline $\operatorname{tet}(\mathrm{W})$ & + & + & + & + & + & + & + & + & + & + & + & + & + & + & + & + \\
\hline $\operatorname{tet}(\mathrm{Y})$ & - & - & + & + & + & + & + & - & + & + & + & + & + & + & + & + \\
\hline $\operatorname{tet}(\mathrm{Z})$ & + & + & + & + & - & + & + & + & + & + & + & + & + & + & + & + \\
\hline
\end{tabular}

Detailed results of positive findings of tetracycline-resistance determinants per soil sample. Pure soil: soil before microcosm setup; slurry: slurry before microcosm setup; water control: control without slurry amendment after 8 days; slurry control: soil with slurry amendment after 8 days; oxytetracycline and tetracycline treatments: after 8 days' exposure with slurry amendment. In pig manure, tet(B), tet(E), tet(M), and tet(O) were also found. These four were also tested in selected soil samples (highest or second highest OTC and TC treatments), but were not found in any of these.

\section{Field Experiments: Time Course of Resistance Genes After Manuring of a} Swiss Soil

The manure used in the Swiss field experiment was obtained from a farm where chlortetracycline, sulfamethazine, and tylosin are used on a regular basis. A variety of resistance determinants was found (Table 3 and Fig. 1). All 3 sulfonamide and 11 tetracycline resistance genes were detected. However, sul(III) and tet(Z) were detected only in one of the manure samples. 


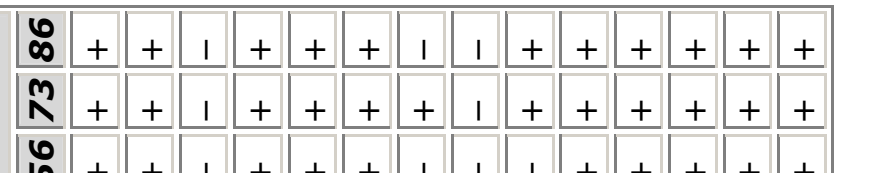

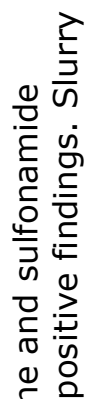

บ눈

ปิ

$\stackrel{ \pm}{ \pm} \frac{0}{2}$

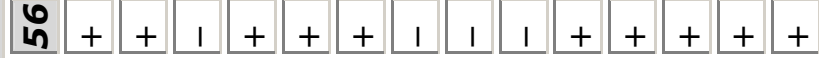

$\dot{q}++1++++1++++++$

$\stackrel{\bullet}{\&}++1++++1++++++$

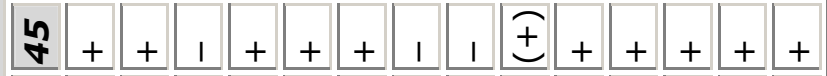

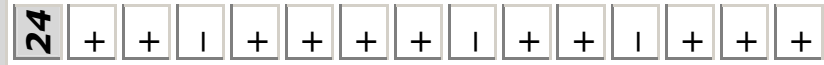

y $+1+1++++1++++++$

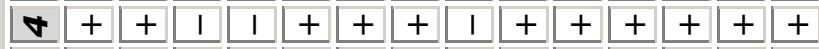

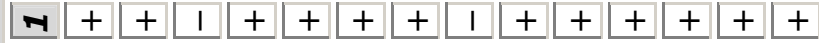

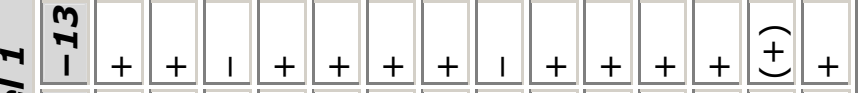

$4 \underset{0}{4}$

ᄀ号

i⿱⿲丶丶㇒一八

중

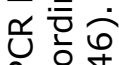

0 定

离苋

ए

$\because \frac{1}{i}$ 음

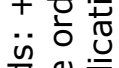

is

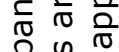

를

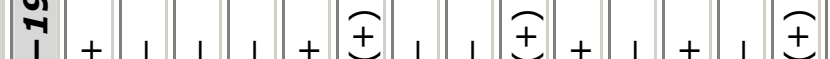

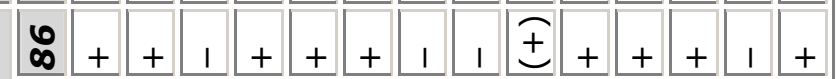

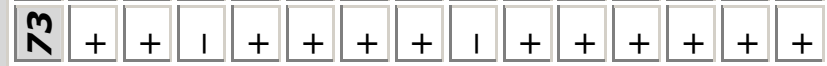

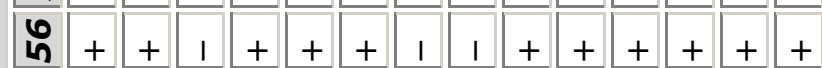

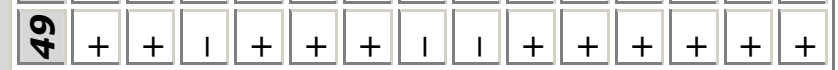

$\stackrel{i}{i}+1+1+++1++++++$

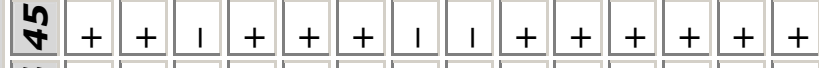

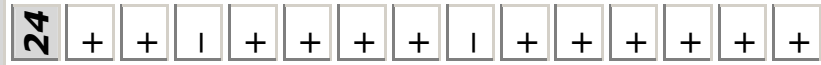

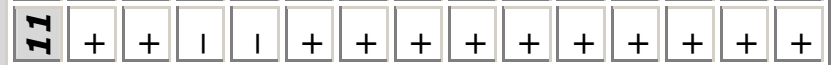

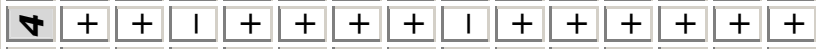

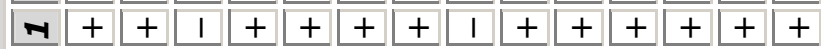

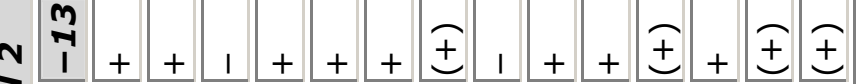

ฮิ

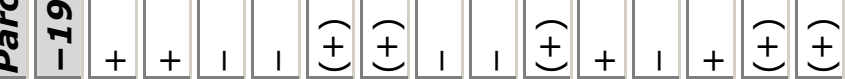

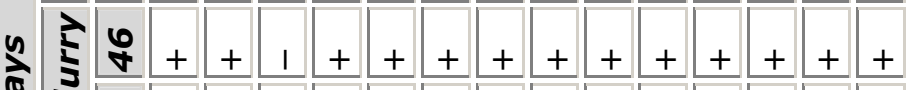

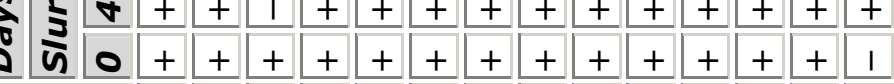

U.

O

돌

ज范

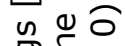

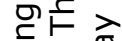

¿

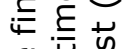

$\sum \stackrel{0}{i}$

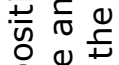

운응 눙

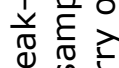

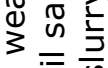

Do

更过

$\sum \stackrel{2}{\square}$

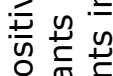

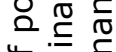

㟧

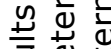

岛告过

잉

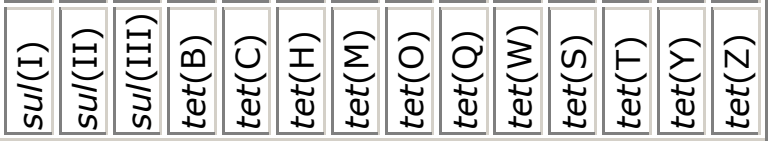

몬

政

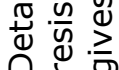




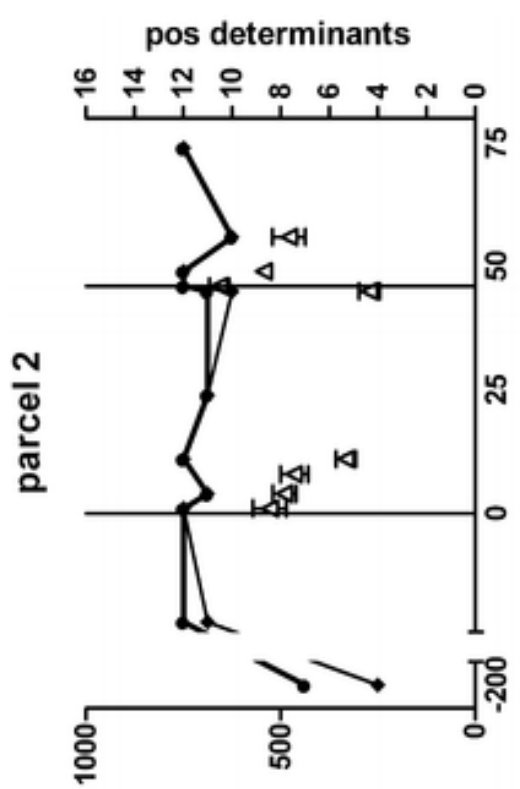

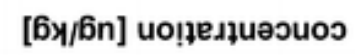

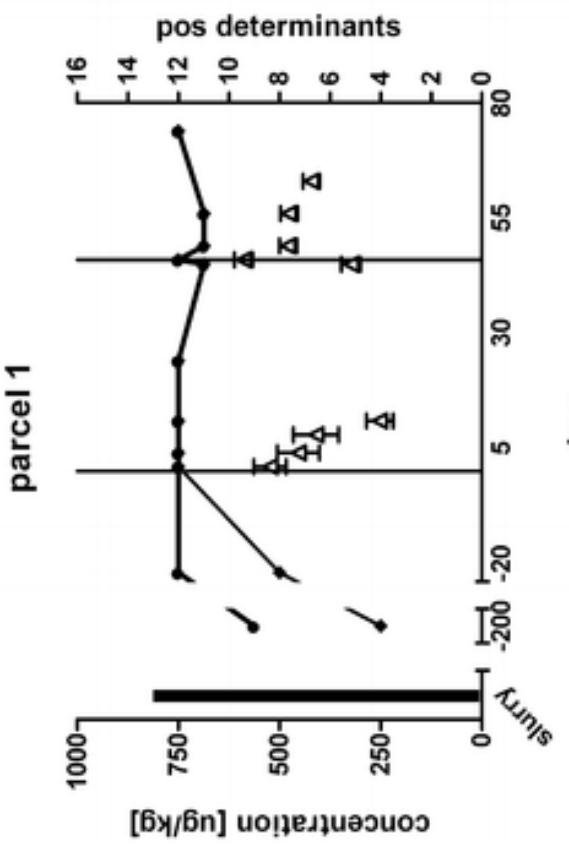

믄 4

든 음 음

त 30

勿的苋

$\frac{1}{4} \stackrel{ \pm}{ \pm}$

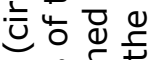

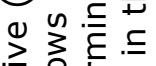

응 눙

ปั

듬

प잉

넝 3

5 过

잉

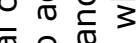

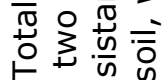

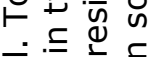

$\dot{\overline{0}} \div \frac{1}{0} \cong$

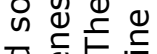

ब

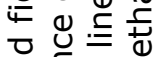

인 들 므

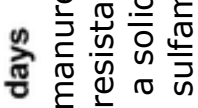

定分

论음

उ $\overline{\mathrm{E}}$ 음

ज苋苋茎

ㄴㅇㅇ 온

u $\overrightarrow{3} . \leq$

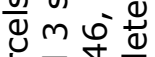

뭉

증 त

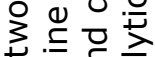

工式分

才。

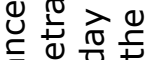

证过

包丈 ㄷㅇㅇ

प्र

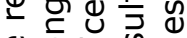

๑ 잉

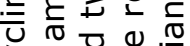

才ิ

逮的造

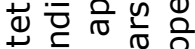

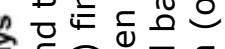

要宁包造 믕

은

응 잉

$\varepsilon$ ह

든

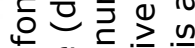

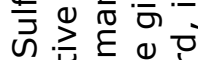

-

0 음

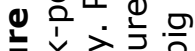

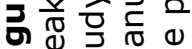

는 
The soil samples taken before manure application showed a varying diversity of resistance genes: The samples taken in autumn of the previous year gave only weak signals for many resistance genes, and $\operatorname{tet}(\mathrm{O})$, tet(M), tet(B), tet(S), and sul(III) could not be detected in these soils (Fig. 1, Table 3 ). In contrast, the spring soils 2 weeks before manure application gave signals for all resistance determinants except sul(III) and tet(O). There was little difference between the soil samples taken before and after both manuring events, in spring and summer.

Most resistance genes were consistently detected over the whole sampling period. Only tet(M) gave no signal in autumn, 1 day before the second manuring (day 45), and on days 56 and 84 . Furthermore, tet(B) and tet(S) once gave a negative signal after manuring. When the total number of genes detected is calculated, there is thus little variation between all soil samples, with the exception of the autumn samples (day -199 in Fig. 1).

\section{Field Experiments: Resistance in Agricultural Soils in Germany}

Ten tetracycline and sulfonamide resistance determinants were detected in a soil that had received pig manure in the last 2 years, among them sul(I), sul(II), $\operatorname{tet}(\mathrm{Y}), \operatorname{tet}(\mathrm{S}), \operatorname{tet}(\mathrm{C}), \operatorname{tet}(\mathrm{Q}), \operatorname{tet}(\mathrm{T}), \operatorname{tet}(\mathrm{H}), \operatorname{tet}(\mathrm{Z})$, and $\operatorname{tet}(\mathrm{W})($ Table 4$)$. All of these genes, plus tet(M) and tet(B) were found in pig manure used for this soil. These genes were, however, not found in the soil $2 \mathrm{~h}$ after manuring, indicating concentrations below the detection limit. The soil amended with cow manure was sampled directly before and 212 days after manuring in order to get an impression of the background of resistance present in this soil. In this soil, tet(S) and $\operatorname{tet}(\mathrm{C})$ were not detected.

Table 4 Sulfonamide and tetracycline resistance in manured field soils in Germany

\begin{tabular}{|c|c|c|c|c|c|c|c|}
\hline & \multicolumn{3}{|c|}{ Pig manure history } & \multicolumn{4}{|c|}{ Cow manure history } \\
\hline & \multirow{2}{*}{$\begin{array}{l}1 \text { h before } \\
\text { manuring }\end{array}$} & \multirow{2}{*}{$\begin{array}{l}\text { Pig } \\
\text { manure }\end{array}$} & \multirow{2}{*}{$\begin{array}{l}2 h \text { after } \\
\text { manuring }\end{array}$} & \multicolumn{2}{|c|}{\begin{tabular}{|l|}
1 h before \\
manuring
\end{tabular}} & \multicolumn{2}{|c|}{$\begin{array}{l}212 \text { days after } \\
\text { manuring }\end{array}$} \\
\hline & & & & $\begin{array}{l}0- \\
10 \mathrm{~cm}\end{array}$ & $\begin{array}{l}10- \\
20 \mathrm{~cm}\end{array}$ & $0-10 \mathrm{~cm}$ & $10-20 \mathrm{~cm}$ \\
\hline sul(I) & + & + & - & + & - & - & + \\
\hline sul(II) & - & + & + & + & + & + & + \\
\hline sul(III) & - & - & - & - & - & - & - \\
\hline $\operatorname{tet}(\mathrm{A})$ & - & - & - & - & - & - & - \\
\hline $\operatorname{tet}(\mathrm{B})$ & - & + & - & - & - & - & - \\
\hline $\operatorname{tet}(\mathrm{C})$ & + & + & + & - & - & - & - \\
\hline $\operatorname{tet}(\mathrm{E})$ & - & - & - & - & - & - & - \\
\hline $\operatorname{tet}(\mathrm{H})$ & + & + & + & + & + & + & + \\
\hline $\operatorname{tet}(\mathrm{M})$ & - & + & - & - & - & - & - \\
\hline $\operatorname{tet}(\mathrm{O})$ & - & - & - & - & - & - & - \\
\hline $\operatorname{tet}(\mathrm{Q})$ & + & + & + & + & + & + & + \\
\hline $\operatorname{tet}(\mathrm{S})$ & + & + & + & - & - & - & - \\
\hline $\operatorname{tet}(\mathrm{T})$ & + & + & + & + & - & + & + \\
\hline $\operatorname{tet}(\mathrm{W})$ & + & + & + & + & - & - & + \\
\hline $\operatorname{tet}(\mathrm{Y})$ & + & + & + & + & + & + & + \\
\hline $\operatorname{tet}(\mathrm{Z})$ & + & + & + & + & + & - & + \\
\hline
\end{tabular}

Detailed results of positive findings of tetracycline and sulfonamide resistance determinants per soil sample and time. The determinants are ordered according to the frequency of positive findings. 


\section{Discussion \\ First Microcosm Experiment: Effects of Manure Versus Spiking with Antibiotics}

In previous studies using the same soil samples as in this study, the oxytetracycline-spiked soil samples showed profound community changes (Schmitt et al., submitted for publication). There, an increase in the community tolerance to oxytetracycline was observed at a concentration of $1.3 \mathrm{mg} \mathrm{kg}^{-1}$, and changes in the molecular diversity were also apparent, as seen in a 16S rDNA denaturing gradient gel electrophoresis analysis (Schmitt, submitted for publication). Thus, there is a surprising divergence between the community changes observed previously and the lack of an oxytetracycline effect on the diversity of tetracycline resistance genes in this investigation (Table 1).

One reason could be that the resistance genes introduced with manure outnumbered the resistance genes present in the soil, possibly masking an increase in the soil-borne genes upon spiking with oxytetracycline. PCR as a qualitative technique will overlook quantitative increases in gene prevalence upon soil antibiotic exposure. Manure had been applied to stimulate bacterial growth and therewith to provoke the bacteriostatic effects of oxytetracycline. As the manure was sampled from a farm with a low-use profile of antibiotics, a high input of resistance genes with the manure was initially not expected. Second, it is possible that other tolerance mechanisms are more important for the tolerance increase observed. There are over 30 tetracycline resistance genes known today [12], and other more general defense mechanisms exist, such as multidrug efflux pumps (Magnet et al. 2001). Still, it is interesting that clear community tolerance changes seem to occur without changes in the diversity of a wide range of tetracycline resistance genes.

\section{Second Microcosm Experiment: Effects of Manure Versus Spiking with Antibiotics}

To test whether manure served as a source of resistance genes, slurry and soil used to set up the microcosms were tested apart in a follow-up experiment. Manure amendment indeed turned out to be the most dominating factor for the soil content of resistance genes (Table 2). Several tetracycline genes [tet(S), tet $(\mathrm{C})$, tet $(\mathrm{Q})$, and $\operatorname{tet}(\mathrm{H})]$ were introduced into the soil via manure. Again, no tetracycline-related changes in resistance gene diversity were observed. This is in contrast to the presence of $>10^{5}$ highly resistant colony-forming units per gram soil in the highest tetracycline treatment (data not shown; Schmitt, accepted for publication). If resistance at this level had been caused by community shifts to a resistance determinant with little presence in the lower treatments, detection of such a resistance gene by PCR should be possible. However, detection limits have not been determined for these soil samples.

In the manure, all 12 tetracycline resistance genes that were tested for were positive. The manure had been sampled from a pig that had not received antibiotic treatment during at least the previous 1.5 months, and originated from a herd where tetracyclines are only used therapeutically in an incidental manner and in a strictly controlled fashion. Resistance in healthy swine and low-use or no-use circumstances has also been documented occasionally $[28,38,40,51$, 52], maybe due to the persistence of resistance genes after ending their use [50]. Even swine feed components might provide a source for resistance genes [6]. However, resistance in bacteria from farm animals has more frequently been linked to the usage patterns of antibiotics $[2,10,31,32,37,40,43]$. 
Still, there were indications that the antibiotics contributed to the persistence of the genes in the soil microcosms. Between 6 and 14 days of soil exposure, the diversity of resistance genes declined most in the manured soil without additional oxytetracycline spiking. The genes not detected on day $14[\operatorname{tet}(\mathrm{C}), \operatorname{tet}(\mathrm{Q}), \operatorname{tet}(\mathrm{H})$ and $\operatorname{tet}(\mathrm{Y})]$ were identical with the ones that were absent or only limitedly found in pure soils and in control soils without pig manure amendment. Possibly, spiking with $15 \mathrm{mg} \mathrm{kg}^{-1}$ oxytetracycline maintains the selection pressure necessary for survival of their hosts in soil or for horizontal transfer. The genes tet(C), tet(Q), and $\operatorname{tet}(\mathrm{H})$ have been frequently detected in isolates associated with the gastrointestinal tract of pigs or other farm animals, such as Bacteroides and Prevotella, Gram-negative enterobacteria, and Pasteurella [27, 38, 39].

In addition, there was a slight increase in the resistance gene prevalence between day 0 (directly after manure and oxytetracycline application) and day 6 . This might suggest preferential growth of the bacteria carrying these resistance genes in the soil samples, which is enhanced in the samples spiked with oxytetracycline.

Not all resistance determinants detected in the manure were found in the soils. The prevalence of tet $(\mathrm{B})$, tet $(\mathrm{M})$, tet $(\mathrm{E})$, and tet $(\mathrm{O})$ in the pig manure could have been so low that they fell below the detection limit when diluted into the soil, or the bacteria carrying these genes might have disappeared upon the change to an aerobic environment. The gene tet(E) mostly resides on nonmobile plasmids, making its transfer to soil bacteria unlikely $[12,16]$. For tet(M) and tet(B), the detection in pig manure but not in soil is more surprising, given that they have the broadest host range known among the tetracycline resistance genes and can be carried on mobile plasmids [12]. Thus, it remains difficult to conclude, from the occurrence of a certain gene in cultured and identified species, the likelihood of occurrence or persistence in other environmental media.

A range of genes seems to be ubiquitous both in the soil and pig manure samples tested: tet( $(\mathrm{T})$, tet(W), and tet( $\mathrm{Z})$. One of these genes, tet(W), has been detected not only in bacteria of the gastrointestinal tract (such as the obligate anaerobes Butyrivibrio [45] and Megasphaera [51]) but also in bacteria typically connected with the soil habitat (such as Actinomyces, Streptomyces, and Bacillus) ([12] and updates of information therein at http://faculty.washington.edu/marilynr/). The gene tet $(T)$ has only been found in the pathogen Streptococcus pyogenes [14], but for tet( $Z)$, its occurrence in the soil bacterium Corynebacterium has been proven [53].

\section{Field Experiments}

The effect of manure fertilization was also investigated in two field studies. The first study was located in Switzerland, on grassland that had received pig manure from nonintensive farming during the last years. Antibiotics were not detected in the soils before the experiment. For the field study, manure from a farm operation with routine antibiotic application was used. Again, pig manure proved to be a reservoir of resistance genes: All tested genes gave positive signals. Both tetracycline and sulfonamide resistance genes were tested, as sulfamethazine had been used in addition to chlortetracycline during swine rearing. However, this time, an influence of manuring on the soil diversity was not apparent. The main reason was the high prevalence of resistance genes in the soils already before pig manure application. Only a few genes that were detectable in pig manure did not reach concentrations high enough to be detected in soil: tet(O) and sul(III).

However, an indication for an effect of manuring on the resistance gene quantity might be inferred from the intensity of the PCR bands. Some genes found both in 
pig manure and in soils were detected with only a weak signal in the spring soil sample of one plot before pig manure spreading, but gave strong signals after manuring $[\operatorname{tet}(\mathrm{M})$, tet( $\mathrm{S})$, tet $(\mathrm{Y})$, and $\operatorname{tet}(\mathrm{Z})]$ (Fig. 2). Furthermore, tet(M) and tet(S) had not been detected 6 months before pig manure spreading and at some later sampling events. These genes might reside in soil at quantities close to the detection limit, and their prevalence might increase after fertilization.

Interestingly, these results mirror the findings from the microcosm experiment, where tet(M) was only detected in pig manure, and tet(S) and tet( $\mathrm{Y})$ only in pig manure and manured soil samples. To confirm the quantitative change upon manuring in resistance determinants, real-time quantitative PCR analysis is under way.

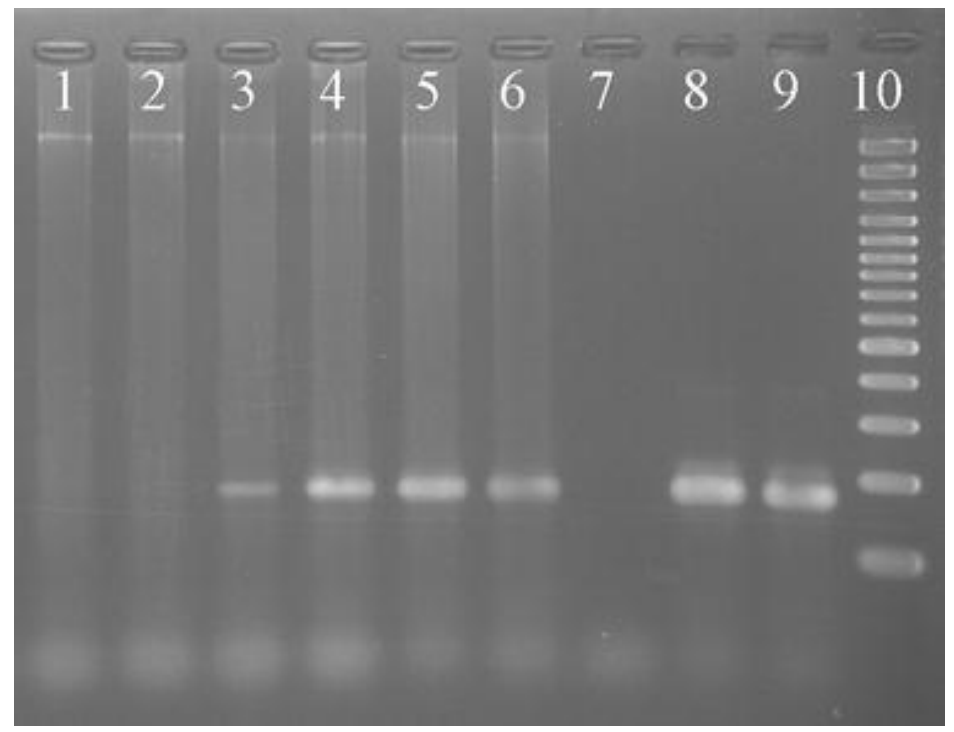

Figure 2 Difference of intensity of PCR bands before and after fertilization with pig manure on the Swiss field site. The PCR reaction of tet(S) is given as an example. Lane 1, 2: autumn samples; lane 3, 4: before fertilization; lane 5, 6: after fertilization; lane 7: negative control; lane 8, 9: positive control; lane 10: 100-bp ladder. Lane 3 gives an example for a weak signal.

The only clear changes in gene prevalence were apparent between the sample taken half a year before pig manure spreading in September and all other samples taken between March and June in the following year. The smaller prevalence of tetracycline resistance genes might be related to a different soil nutrient status and a different standing community of microorganisms. Profound changes in the bacterial community in one soil over the different seasons have been found earlier $[7,23,49]$.

We can only speculate about the reasons for the high prevalence of resistance genes in the Swiss soils. The fields had been fertilized with manure from extensive pig farming in the previous years, and it was only in the year of study that pig manure from a high-usage farm was used. For habitats other than soil, it has been found that a higher prevalence of resistance genes was due to fecal contamination $[2,8,33,34,41]$. However, it has also been suggested that antibiotic resistance genes would be dispersed globally [57]. Furthermore, soil might represent a natural reservoir of resistance genes [44], as it is generally thought that antibiotic resistance genes originate from soil-borne antibiotic producers. 
In the second field study, which was located in an area with intensive farming in Germany, the number of positively detected resistance genes was smaller than in Switzerland. Analytical studies in the same region had shown that little tetracycline residues were found in cow manure, whereas pig manure regularly contained concentrations of tetracyclines in the range of milligrams per kilogram [29]. A higher antibiotic treatment frequency in pig farms would lead to a higher selection pressure and possibly resistance gene prevalence in pig manure. Indeed, in our study the number of tetracycline resistance genes detected was smaller in soils fertilized with cow slurry than in soils fertilized with pig slurry. There was some overlap between the genes found frequently in the German field study and in the microcosm experiments: tet $(W)$, tet $(T)$, and tet( $Z)$ were found in unmanured soils in the microcosm experiment and also in field soils before the first fertilization of the year.

Again, an effect of manuring on the diversity of resistance genes could not be detected. Still, the difference between gene prevalence in the soil and in the manure was small, as only tet(M) and tet(B) were additionally detected in the manure, but not in the soil. These two genes also failed detection in the microcosm soil despite occurrence in the manure.

Overall, differences between tetracycline resistance gene occurrence in environments and regions have been shown. This can also be seen from the comparison with other investigations. In nonmanured soils, Hund-Rinke et al. [30] reported only incidental findings of tet resistance genes, which is in contrast to our studies. Furthermore, in their study, tet(M) and tet(O) were detected in manured microcosms, whereas we only detected tet $(\mathrm{O})$ in manure. Our limited detection of tet(M) in the microcosm and one field experiment is also in contrast to a study on resistance genes in bacteria of the Bacillus group in a manured farm soil in Denmark, where tet(M) was most prevalent [1]. There is one caveat, though, as detection limits have neither been determined in our study nor in most of the studies cited above, and differences might thus also be caused by diverging sensitivities of the PCR reactions. Most notably, there are also many congruencies, especially with an investigation on groundwater samples impacted by a pig farm $[5,11]$ : tet $(\mathrm{W})$ and tet(Q) are elements detected in all studies when tested, and $\operatorname{tet}(\mathrm{H}), \operatorname{tet}(\mathrm{T}), \operatorname{tet}(\mathrm{Z})$ and $\operatorname{tet}(\mathrm{M})$ were regularly observed in at least four out of the seven locations $[1,5,11,30]$.

In conclusion, manure proved to be the determining factor for the diversity of resistance genes in microcosm studies. The contribution of even high concentrations of antibiotics to the resistance gene diversity was comparatively minor, although the antibiotics caused other community adaptation This suggests that other tolerance mechanisms dominate in the microcosms, or that the community tolerance is induced by quantitative changes in the resistance gene prevalence. In contrast, we failed to detect a clear influence of manuring on the diversity of tetracycline resistance genes in field soils. The main reason was the similarity of the resistance gene patterns between manure and soils in both regions, such that an additional impact of the manure was difficult to observe. The diversity of tetracycline resistance in some soils was high. This could be caused by a global spread of resistance genes, or it could highlight the role of soils as a natural reservoir of resistance genes.

Acknowledgments We thank Joanne Chee-Sanford and Vincent Perreten for providing DNA extracts of the positive control strains; Remy Hillekens, Rogier Doornbos, and Karel Wernars for advice and technical assistance; Heinrich Höper (Geological Survey of Lower Saxony, Germany) for experimental setup and sampling of the German field study; and Jan-Dirk van Elsas for critically 
commenting on the progress of work. The Swiss field study was partly financed by the Swiss National Research Program NRP49 "Antibiotic Resistance" (404963282) and the Swiss Agency for the Environment, Forests and Landscape (SAEFL).

\section{References}

1. Agers $\varnothing, Y$, Jensen, LB, Givskov, M, Roberts, MC (2002) The identification of a tetracycline resistance gene tet(M), on a Tn916-like transposon, in the Bacillus cereus group. FEMS Microbiol Lett 214: 251-256

2. Agers $\varnothing, Y$, Sengeløv, G, Jensen, LB (2004) Development of a rapid method for direct detection of tet(M) genes in soil from Danish farmland. Environ Int 30: 117-122

3. American Academy of Microbiology (1999) Antimicrobial Resistance: An Ecological Perspective. American Society for Microbiology. Washington, DC

4. American Academy of Microbiology (2002) The Role of Antibiotics in Agriculture. American Society for Microbiology. Washington, DC

5. Aminov, RI, Chee-Sanford, JC, Garrigues, N, Teferedegne, B, Krapac, IJ, White, BA, Mackie, RI (2002) Development, validation, and application of PCR primers for detection of tetracycline efflux genes of gram-negative bacteria. Appl Environ Microbiol 68: 1786-1793

6. Aminov, RI, Garrigues-Jeanjean, N, Mackie, RI (2001) Molecular ecology of tetracycline resistance: development and validation of primers for detection of tetracycline resistance genes encoding ribosomal protection proteins. Appl Environ Microbiol 67: 22-32

7. Andersen, JT, Schafer, T, Jorgensen, PL, Moller, S (2001) Using inactivated microbial biomass as fertilizer: the fate of antibiotic resistance genes in the environment. Res Microbiol 152: 823-833

8. Andersen, SR, Sandaa, RA (1994) Distribution of tetracycline resistance determinants among gram-negative bacteria isolated from polluted and unpolluted marine sediments. Appl Environ Microbiol 60: 908-912

9. Brady, MS, White, N, Katz, SE (1993) Resistance development potential of antibiotic/antimicrobial residue levels designated as 'safe levels.' J Food Prot 56: 229-233

10. Bryan, A, Shapir, N, Sadowsky, MJ (2004) Frequency and distribution of tetracycline resistance genes in genetically diverse, nonselected, and nonclinical Escherichia coli strains isolated from diverse human and animal sources. Appl Environ Microbiol 70: 2503-2507

11. Chee-Sanford, JC, Aminov, RI, Krapac, IJ, Garrigues-Jeanjean, N, Mackie, RI (2001) Occurrence and diversity of tetracycline resistance genes in lagoons and groundwater underlying two swine production facilities. Appl Environ Microbiol 67: 1494-1502

12. Chopra, I, Roberts, M (2001) Tetracycline antibiotics: mode of action, applications, molecular biology, and epidemiology of bacterial resistance. Microbiol Mol Biol Rev 65: 232-260

13. Chu, C, Chiu, CH, Wu, WY, Chu, CH, Liu, TP, Ou, JT (2001) Large drug resistance virulence plasmids of clinical isolates of Salmonella enterica serovar Choleraesuis. Antimicrob Agents Chemother 45: 2299-2303

14. Clermont, D, Chesneau, O, De Cespedes, G, Horaud, T (1997) New tetracycline resistance determinants coding for ribosomal protection in streptococci and nucleotide sequence of tet( $T$ ) isolated from Streptococcus pyogenes A498. Antimicrob Agents Chemother 41: 112-116

15. De Liguoro, M, Cibin, V, Capolongo, F, Halling-Sorensen, B, Montesissa, C (2003) Use of oxytetracycline and tylosin in intensive calf farming: evaluation of transfer to manure and soil. Chemosphere 52: 203-212 
16. DePaola, A, Roberts, MC (1995) Class D and E tetracycline resistance determinants in Gramnegative bacteria from catfish ponds. Mol Cell Probes 9: 311-31

17. Esiobu, N, Armenta, L, Ike, J (2002) Antibiotic resistance in soil and water environments. Int J Environ Health Res 12: 133-144

18. FAO/OIE/WHO (2003) First Joint FAO/OIE/WHO Expert Workshop on Non-human Antimicrobial Usage and Antimicrobial Resistance: Scientific Assessment. FAO/OIE/WHO, Geneva

19. FEDESA (1999) Antibiotics for Animals. FEDESA. Brussels

20. Garbeva, P, van Veen, JA, van Elsas, JD (2003) Predominant Bacillus spp. in agricultural soil under different management regimes detected via PCR-DGGE. Microb Ecol 45: 302-316

21. Götz, A, Smalla, K (1997) Manure enhances plasmid mobilization and survival of Pseudomonas putida introduced into field soil. Appl Environ Microbiol 63: 1980-1986

22. Grape, M, Sundstrom, L, Kronvall, G (2003) Sulphonamide resistance gene sul3 found in Escherichia coli isolates from human sources. J Antimicrob Chemother 52: 1022-1024

23. Griffiths, RI, Whiteley, AS, O'Donnell, AG, Bailey, MJ (2003) Influence of depth and sampling time on bacterial community structure in an upland grassland soil. FEMS Microbiol Ecol 43: 35-43

24. Halling-Sørensen, B, Nielsen, S, Lanzky, PF, Ingerslev, F, Lützhøft, HC, Jørgensen, SE (1998) Occurrence, fate and effects of pharmaceutical substances in the environment-a review. Chemosphere 36: 357-393

25. Hamscher, G, Pawelzick, HT, Höper, H, Nau, H (2005) Different behaviour of tetracyclines and sulfonamides in sandy soils after repeated fertilization with liquid manure. Environ Toxicol Chem 24: $861-868$

26. Hamscher, G, Sczesny, S, Höper, H, Nau, H (2002) Determination of persistent tetracycline residues in soil fertilized with liquid manure by high-performance liquid chromatography with electrospray ionization tandem mass spectrometry. Anal Chem 74: 1509-1518

27. Hansen, LM, Blanchard, PC, Hirsh, DC (1996) Distribution of tet(H) among Pasteurella isolates from the United States and Canada. Antimicrob Agents Chemother 40: 1558-1560

28. Heuer, H, Krögerrecklenfort, E, Wellington, EMH, Egan, S, van Elsas, JD, van Overbeek, L, Collard, J-M, Guillaume, G, Karagouni, AD, Nikolakopoulou, TL, Smalla, K (2002) Gentamicin resistance genes in environmental bacteria: prevalence and transfer. FEMS Microbiol Ecol 42: 289-302

29. Höper, H, Kues, H, Nau, H, Hamscher, G (2002) Eintrag und Verbleib von Tierarzneimittelwirkstoffen in Böden. Bodenschutz 4: 141-148

30. Hund-Rinke, K, Simon, M, Lukow, T (2004) Effects of tetracycline on the soil microflora: function, diversity, resistance. J Soils Sediments 4: 11-16

31. Huysman, F, van Renterghem, B, Verstraete, W (1993) Antibiotic resistant sulphite-reducing clostridia in soil and groundwater as indicator of manuring practices. Water Air Soil Pollut 69: 243-255

32. Jackson, CR, Fedorka-Cray, PJ, Barrett, JB, Ladely, SR (2004) Effects of tylosin use on erythromycin resistance in enterococci isolated from swine. Appl Environ Microbiol 70: 4205-4210

33. Jensen, LB, Agerso, Y, Sengelov, G (2002) Presence of erm genes among macrolide-resistant Gram-positive bacteria isolated from Danish farm soil. Environ Int 28: 487-491

34. Jensen, LB, Baloda, S, Boye, M, Aarestrup, FM (2001) Antimicrobial resistance among 
Pseudomonas spp. and the Bacillus cereus group isolated from Danish agricultural soil. Environ Int 26: $581-587$

35. Kay, P, Blackwell, PA, Boxall, AB (2004) Fate of veterinary antibiotics in a macroporous tile drained clay soil. Environ Toxicol Chem 23: 1136-1144

36. Korthals, GW, Alexiev, AD, Lexmond, TM, Kammenga, JE, Bongers, T (1996) Long-term effects of copper and $\mathrm{pH}$ on the nematode community in an agroecosystem. Environ Toxicol Chem 15: 979985

37. Lanz, R, Kuhnert, P, Boerlin, P (2003) Antimicrobial resistance and resistance gene determinants in clinical Escherichia coli from different animal species in Switzerland. Vet Microbiol 91: 73-84

38. Lee, C, Langlois, BE, Dawson, KA (1993) Detection of tetracycline resistance determinants in pig isolates from three herds with different histories of antimicrobial agent exposure. Appl Environ Microbiol 59: 1467-1472

39. Leng, Z, Riley, DE, Berger, RE, Krieger, JN, Roberts, MC (1997) Distribution and mobility of the tetracycline resistance determinant tetQ. J Antimicrob Chemother 40: 551-559

40. Mathew, AG, Saxton, AM, Upchurch, WG, Chattin, SE (1999) Multiple antibiotic resistance patterns of Escherichia coli isolates from swine farms. Appl Environ Microbiol 65: 2770-2772

41. Onan, L, LaPara, TM (2003) Tylosin-resistant bacteria cultivated from agricultural soil. FEMS Microbiol Lett 220: 15-20

42. Perreten, V, Boerlin, $\mathrm{P}$ (2003) A new sulfonamide resistance gene (su/3) in Escherichia coli is widespread in the pig population of Switzerland. Antimicrob Agents Chemother 47: 1169-1172

43. Rajic, A, McFall, ME, Deckert, AE, Reid-Smith, R, Manninen, K, Poppe, C, Dewey, CE, McEwen, SA (2004) Antimicrobial resistance of Salmonella isolated from finishing swine and the environment of 60 Alberta swine farms. Vet Microbiol 104: 189-196

44. Riesenfeld, CS, Goodman, RM, Handelsman, J (2004) Uncultured soil bacteria are a reservoir of new antibiotic resistance genes. Environ Microbiol 6: 981-989

45. Roberts, MC (2003) Acquired tetracycline and/or macrolide-lincosamides-streptogramin resistance in anaerobes. Anaerobe 9: 63-69

46. Rooklidge, SJ (2004) Environmental antimicrobial contamination from terraccumulation and diffuse pollution pathways. Sci Total Environ 325: 1-13

47. Sczesny, S, Nau, H, Hamscher, G (2003) Residue analysis of tetracyclines and their metabolites in eggs and in the environment by HPLC coupled with a microbiological assay and tandem mass spectrometry. J Agric Food Chem 51: 697-703

48. Sengeløv, G, Agersø, Y, Halling-Sørensen, B, Baloda, SB, Andersen, J, Jensen, LB (2003) Bacterial antibiotic resistance levels in Danish farmland as a results of treatment with pig manure slurry. Environ Int 28: 587-595

49. Smit, E, Leeflang, P, Gommans, S, van den Broek, J, van Mil, S, Wernars, K (2001) Diversity and seasonal fluctuations of the dominant members of the bacterial soil community in a wheat field as determined by cultivation and molecular methods. Appl Environ Microbiol 67: 2284-2291

50. Smith, HW (1975) Persistence of tetracycline resistance in pig E. coli. Nature 258: 628-630

51. Stanton, T, McDowall, JS, Rasmussen, MA (2004) Diverse tetracycline resistance genotypes of Megasphaera elsdenii strains selectively cultured from swine feces. Appl Environ Microbiol 70: 3754-3757 
Microbial Ecology Volume 51, Number 3 / April, 2006 Pages 267-276

52. Stanton, TB, Humphrey, SB (2003) Isolation of tetracycline-resistant Megasphaera elsdenii strains with novel mosaic gene combinations of $\operatorname{tet}(\mathrm{O})$ and tet(W) from swine. Appl Environ Microbiol 69: 3874-3882

53. Tauch, A, Puhler, A, Kalinowski, J, Thierbach, G (2000) TetZ, a new tetracycline resistance determinant discovered in gram-positive bacteria, shows high homology to gram-negative regulated efflux systems. Plasmid 44: 285-291

54. Ungemach, FR (2000) Figures on quantities of antibacterials used for different purposes in the EUcountries and interpretation. Acta Vet Scand 93: 89-98

55. Overbeek, LS van, Wellington, EMH, Egan, S, Smalla, K, Heuer, H, Collard, J-M, Guillaume, G, Karagouni, AD, Nikolakopoulou, TL, van Elsas, JD (2002) Prevalence of streptomycin-resistance genes in bacterial populations in European habitats. FEMS Microbiol Ecol 42: 277-288

56. WHO (2001) Global Strategy for Containment of Antimicrobial Resistance. Report No. WHO/CDS/CSR/DRS/2001.2a. World Health Organisation, Geneva

57. Witte, W (1998) Medical consequences of antibiotic use in agriculture. Science 279: 996-997 